\title{
Evaluation of microirrigation levels for growth and productivity of avocado trees ${ }^{1,2}$
}

\author{
Elvin Román-Paoli ${ }^{3}$,Félix M. Román-Pérez $z^{4}$ and \\ José Zamora-Echevarria ${ }^{5}$
}

J. Agric. Univ. P.R. 93(3-4):173-186 (2009)

\begin{abstract}
Avocado (Persea americana Mill. cv. Simmonds) is an important fruit among consumers in Puerto Rico and in the Hispanic community in the United States. During the last years, orchard establishment has increased considerably in Puerto Rico, where production of this fruit is third behind mango and oranges. Currently growers need to deal with lack of information on proper irrigation management in orchards under conditions observed in Puerto Rico. Typically, growers are encouraged to adopt an irrigation scheduling method to ensure tree establishment and adequate productivity, and thus to reduce problems associated with improper irrigation management. The Universities of Puerto Rico and Florida recommend the use of tensiometers to schedule irrigation for fruit trees. An avocado orchard was established during 2001 for evaluating the effect of soil water tension measured by tensiometers on growth and productivity of avocado trees under microirrigation. The predominant soil series at the experimental site is Coto clay, classified as Typic Eutrustox. Planting distance was $9.1 \mathrm{~m} \times 9.1 \mathrm{~m}$. Trees were submitted to two microirrigation treatments scheduled by using tensiometers installed at $30-\mathrm{cm}$ and $45-\mathrm{cm}$ depths. Trees were irrigated when tensiometer readings reached a low depletion level ( 10 to $15 \mathrm{kPa}$ ) or a high depletion level (40 to $45 \mathrm{kPa}$ ). A rainfed treatment was included as check. Variables measured were canopy volume, fruit weight and number, and irrigation applied. Canopy volume of trees growing under rainfed conditions was significantly lower than that of trees submitted to either 10 to $15 \mathrm{kPa}$ or 40 to $45 \mathrm{kPa} \mathrm{mi}$ croirrigation treatment. Trees submitted to 40 to $45 \mathrm{kPa}$ showed the maximum canopy volume, $148 \mathrm{~m}^{3} /$ tree, which was not significantly different from that of trees submitted to 10 to $15 \mathrm{kPa}$. Only in 2005, trees irrigated at low depletion levels produced 68 fruits per tree, an amount which was significantly greater than that of the other two irrigation treatments. In general, avocado trees submitted to high depletion level significantly increased their growth and yield.
\end{abstract}

${ }^{1}$ Manuscript submitted to Editorial Board 25 March 2008.

${ }^{2}$ The authors thank Edwin Monroig for experiment management and data collection, and Miguel Vázquez for determining the water retention curves in the Soil Physics Laboratory at Río Piedras, University of Puerto Rico. This research was initially funded by a special project grant (SP-329) from the University of Puerto Rico and was continued with funds of a Hatch Regional grant H-402 (W-1128).

${ }^{3}$ Professor, Department of Crops and Agroenvironmental Sciences, College of Agricultural Sciences, Univ. of Puerto Rico, Mayagüez Campus, HC-02 Box 11656, Lajas, PR 00667-9714. Email address: elvin.roman@upr.edu

${ }^{4}$ Professor, Department of Crops and Agroenvironmental Sciences.

${ }^{5}$ Associate Professor, Department of Crops and Agroenvironmental Sciences. 
Key words: microirrigation, evapotranspiration, tensiometers, avocado

\section{RESUMEN}

Niveles de microriego y su efecto sobre el crecimiento y productividad de árboles de aguacate

El aguacate (Persea americana Mill. cv. Simmonds) es una fruta de mucha importancia en Puerto Rico y en la comunidad Latina en los Estados Unidos. En los últimos años, el establecimiento de huertos de aguacate en Puerto Rico ha aumentado considerablemente; la producción de esa fruta se colocó tercera, después de la de mango y la de las chinas. Para asegurar el establecimiento de los árboles, la productividad y la reducción de los problemas asociados al manejo inapropiado del riego, se promueve que los productores adopten algún método para calendarizar el microriego. La Universidad de Puerto Rico y la Universidad de Florida recomiendan el uso de tensiómetros para calendarizar el microriego en árboles frutales. En el 2001 se sembró un huerto de aguacate para establecer un experimento para evaluar el efecto de la tensión hídrica, medida con tensiómetros, en el crecimiento y productividad de árboles de aguacate bajo microriego. La serie de suelo predominante en el predio experimental es Coto arcilloso, clasificado como Typic Eutrustox. La distancia de siembra de los árboles fue de $9.1 \mathrm{~m} \times 9.1 \mathrm{~m}$. Los árboles se sometieron a dos tratamientos de microriego calendarizados utilizando tensiómetros instalados a 30 y $45 \mathrm{~cm}$ de profundidad. En ambos tratamientos, los árboles se regaban cuando la tensión hídrica del suelo alcanzaba los valores críticos predeterminados, entre 10 y $15 \mathrm{kPa}$ y entre 40 y $45 \mathrm{kPa}$. Se incluyó un tercer tratamiento sin riego como testigo. Las variables utilizadas para medir la respuesta de los árboles a los tratamientos de microriego fueron rendimiento, volumen de la copa, número y peso de frutas por árbol, y la cantidad de riego aplicada. El volumen de la copa de los árboles a los cuales no se les aplicaba microriego fue significativamente menor que el de los árboles con los dos tratamientos de microriego probados. EI volumen de la copa máximo registrado fue de $148 \mathrm{~m}^{3} / a ́ r b o l$, obtenido cuando la tensión hídrica del suelo alcanzaba de 40 a $45 \mathrm{kPa}$; éste no fue significativamente diferente al obtenido cuando se regaba a 10 a $15 \mathrm{kPa}$. EI rendi-


la tensión superaba los 40 a $45 \mathrm{kPa}$. Solo en el 2005 , el número de frutas por árbol en el tratamiento 10 a $15 \mathrm{kPa}$ superó significativamente a los demás tratamientos, con 68 frutas por árbol. En términos generales, los árboles de aguacate sometidos a una tensión hídrica en el suelo de 40 a $45 \mathrm{kPa}$ produjeron significativamente mayor crecimiento y rendimiento.

Palabras clave: microriego, evapotranspiración, tensiómetros, aguacate, cv. Simmonds

\section{INTRODUCTION}

Mexico, Chile and the United States dominate avocado production worldwide, with Mexico being the largest producer, supplying over onethird of the world total production (WHTUSEO, 2006). In Puerto Rico, avocado is becoming a major commodity among fruits because of favorable growing conditions and the potential for obtaining high yield and high fruit quality. Factors such as avocado diseases, inadequate orchard management, and poor edaphic conditions limit avocado production in northwest and southwest Puerto Rico. Limited information is 
available on avocado growth and yield response as influenced by irrigation. For example, improper management of irrigation may increase the incidence of Phytophthora cinnamomi in the root system or may cause nutrient losses through the soil profile. The goal of an irrigationscheduling program is to provide growers with guidelines for timely and adequate irrigation to increase yield. Through proper irrigation, it should be possible to apply the amount of water that matches crop evapotranspiration, thus reducing water and nitrogen losses.

The University of Puerto Rico and the University of Florida recommend the use of tensiometers to schedule irrigation (Goyal, 1989; Li, 2000 ). In Puerto Rico, research in irrigation has been oriented mostly toward fruits such as banana and papaya and toward vegetable crops (Goenaga and Irizarry, 1995; Goyal, 1989). In California and Florida, research on irrigation has been conducted mostly on avocado management and production. However, differences in soil and climate conditions make difficult the transfer of all of this information to Puerto Rico. Providing local avocado growers with accurate information on the amount of irrigation needed, and on expected yield and growth responses, requires further research. Thus, the objective of this research was to evaluate the effect of soil water tension on growth and productivity of young avocado trees grown on an Oxisol in Puerto Rico, with microirrigation.

\section{MATERIALS AND METHODS}

An avocado orchard was established at the Isabela Agricultural Experiment Substation located in Northern Puerto Rico $\left(18^{\circ} 27^{\prime} \mathrm{N}\right.$ and $67^{\circ} 03^{\prime} \mathrm{W}$ ). The soil series at the experimental site is a well-drained, very fine Oxisol, kaolinitic, isohyperthermic Typic Eutrustox (Beinroth, 2003), with the following chemical characteristics: $\mathrm{pH}, 5.3$; organic matter, 2.7\%; Zn, $2.4 \mathrm{mg} / \mathrm{kg}$; $\mathrm{Mn}, 112 \mathrm{mg} / \mathrm{kg} ; \mathrm{Fe}, 6 \mathrm{mg} / \mathrm{kg}$; Cu, $8.9 \mathrm{mg} / \mathrm{kg}$; P (Bray 1), $19 \mathrm{mg} / \mathrm{kg}$; K, $252 \mathrm{mg} / \mathrm{kg}$; Ca, $960 \mathrm{mg} / \mathrm{kg} ; \mathrm{Mg}, 47 \mathrm{mg} / \mathrm{kg}$; and $\mathrm{CEC}, 8.5 \mathrm{cmol} / \mathrm{kg}$.

Avocado trees (Persea americana Mill. cv. Simmonds) grafted on 'Gripiña' rootstock were planted 4 October 2001 at a distance of $9.1 \mathrm{~m}$ $\times 9.1 \mathrm{~m}$. Trees were submitted to a formative pruning during the first year to induce lateral branching and a single trunk within the first meter. Branch pruning continued every year after harvest. Other management practices followed the recommendations of the Technological Package for Avocado Production (AES, 1998). Cultivar Simmonds belongs to the West Indian race and produces a green fruit, with an average fruit weight ranging from 450 to $950 \mathrm{~g}$. Maturity dates occur between 25 June and 15 September (Crane et al., 2000). 
During the first two years of growth, trees were fertilized every three months with a 15-5-10-3 granular formulation at a rate of 2.27 $\mathrm{kg} /$ tree. After the third year, we used the formulation 12-6-16-3 at the same rate as the previous year. Rows were kept weed free with regular glyphosate applications; vegetation between rows was mown periodically.

During the first year, irrigation was applied by using $7.57 \mathrm{~L} / \mathrm{h}$ button drippers, installed on polytubing lines with a diameter of $1.9 \mathrm{~cm}$. Drippers were replaced by micro-sprinklers with a discharge capacity of $29.07 \mathrm{~L} / \mathrm{h}$; these sprinklers apply water to a diameter of $3.8 \mathrm{~m}$ providing a wetted area of approximately $11.8 \mathrm{~m}^{2} /$ tree. Lateral distribution of the system allowed independent water applications to each plot. The micro-sprinklers were installed on plastic stakes under the canopy and raised about $20 \mathrm{~cm}$ from soil surface. The area covered by the root system of the trees was assumed to be similar to mean canopy diameter. To estimate sprinkler discharge variability to compensate for pressure losses in the irrigation system, five micro-sprinklers were randomly selected and the actual water discharge was measured at a system pressure of $138 \mathrm{kPa}$ (20 PSI) at the water intake. The irrigation delivered to the plots was adjusted by using the actual water discharge. The volume of water applied per irrigation event was calculated to wet the soil to field capacity. Soil water retention curves were determined in the soil physics laboratory.

Avocado trees were submitted to three microirrigation treatments. In two of the treatments, trees were irrigated when tensiometers reached a low depletion level (10 to $15 \mathrm{kPa}$ ) and high depletion level (40 to $45 \mathrm{kPa}$ ). A third treatment, consisting of rainfed trees, was included as a check. Irrigation was applied based on average tensiometer readings taken three times per week per plot. These instruments were installed at 30$\mathrm{cm}$ and $45-\mathrm{cm}$ depths and one meter away from the trunk. Soil water tension was measured at each plot by using a digital pocket tensiometer (Soil Measurement System, Tucson, AZ) ${ }^{6}$. Soil tension at both depths was averaged to obtain an average soil water tension per plot. Water applied per treatment was registered by flow meters.

The experimental plots were arranged in a randomized complete block design with four replications. Plots consisted of five trees, and data were collected from the middle four. Soil samples were taken to the laboratory for water retention curve determination.

\footnotetext{
${ }^{6}$ Company and trade names in this publication are used only to provide specific information. Mention of a company or trade name does not constitute a warranty of equipment or materials by the Agricultural Experiment Station of the University of Puerto Rico, nor is this mention a statement of preference over other equipment or materials.
} 
A computer model developed by Harmsen and González (2005) which estimates reference evapotranspiration (ET) and crop evapotranspiration was used to compare the irrigation applied to each treatment with an estimate of the trees' water consumption. Table 1 shows the input used by the model to estimate avocado's ET. The program calculates the initial crop coefficient $(\mathrm{Kc})$ value. The $\mathrm{Kc}$ for the mid and final stages of development of the avocado trees was 0.85 and 0.75 , respectively, and maximum plant height was set to three meters (Allen et al., 1998). The computer program estimates ET on a daily basis for a one-year period using four stages of growth and development: initial stage, development stage, mid-stage (mature), and end stage. The length of each stage was established arbitrarily to $50,120,105$, and 90 days, respectively (Table 1). Estimation of ET began 1 January and ended 31 December of the same year.

The response variables measured were canopy volume, fruit number, fruit weight, and amount of water applied. Tree canopy volume was calculated by using the same approach utilized by Román et al. (1997). Yearly data were statistically analyzed by analysis of variance, and mean separation by using Fisher's LSD at the 5\% probability level (SAS Institute, 2002).

\section{RESULTS AND DISCUSSION}

Personnel of the soil physics laboratory at the University of Puerto Rico estimated water retention values for Coto clay at the experimental

TABLE 1.-Inputs to estimate avocado ET at Isabela, Puerto Rico, from 2003 to 2005.

\begin{tabular}{lc}
\hline Input & Value \\
\hline Latitude & $18.47^{\circ} \mathrm{N}$ \\
Elevation & $126 \mathrm{~m}$ \\
Length of initial crop stage & 50 days \\
Length of development crop stage & 120 days \\
Length of mid (mature) crop stage & 105 days \\
Length of end crop stage & 90 days \\
Interval between irrigation & 4 days \\
Depth of irrigation & 45 mm \\
Type of soil & coarse \\
Climate zone & northern slopes \\
Wind speed measured & $2 \mathrm{~m}$ \\
Mid stage Ke & 0.85 \\
End stage Kc & 0.75 \\
Maximum crop height & $3 \mathrm{~m}$ \\
\hline
\end{tabular}

${ }^{1}$ For simulation purpose, the variable type of soil was set to coarse (instead of clayey) because Coto series exhibits high water percolation through the profile, even though it is classified as a clayey soil. 
site (data not shown). Field capacity (10 to $15 \mathrm{kPa}$ ) volumetric water content $(\theta)$ values varied from 38.9 to $37.5 \%$. Permanent wilting point estimate was $\theta=20.7 \%$, resulting in total available water of $18.2 \%$. For 40 to $45 \mathrm{kPa}$ treatment, $\theta$ varied from 33.9 to $33.5 \%$. The $\theta$ difference between treatments 10 to 15 and 40 to $45 \mathrm{kPa}$ was about $5.0 \%$. In spite of the small difference in $\theta$ between microirrigation treatments, the tendency is that avocado responds better when soil tension is less than 40 to $45 \mathrm{kPa}$.

Response of tree canopy volume to microirrigation treatments was significant during 2003 and 2004, whereas response was highly significant in 2005 and 2006 (Table 2). During the four-year period, trees submitted to rainfed treatment (no microirrigation) showed significantly less canopy volume than those with irrigation treatments (Figure 1). Trees submitted to 40 to $45 \mathrm{kPa}$ soil tension in 2005 produced a significantly higher canopy volume $\left(147 \mathrm{~m}^{3} /\right.$ tree $)$ than trees submitted to 10 to $15 \mathrm{kPa}\left(104 \mathrm{~m}^{3} /\right.$ tree $)$ whereas no significant differences were detected among irrigation treatments in 2006. The lack of response in terms of canopy volume could be attributed to high rainfall registered during 2005 (Table 3).

The avocado orchard was harvested for the first time August 2004. As trees grew older, microirrigation treatments affected production. In 2005, when soil tension was near field capacity (10 to $15 \mathrm{kPa}$ ), avocado trees produced $49 \mathrm{~kg}$ fruit per tree, yield which was significantly higher than that obtained for the $40-$ to $45-\mathrm{kPa}$ and rainfed treatments. In 2006 , trees submitted to 40 - to $45-\mathrm{kPa}$ soil water tension treatment produced the highest yield, with $84 \mathrm{~kg}$ fruit per tree (Figure 2 ). No significant differences in fruit number were detected in 2004 and 2006 (Table 2). In 2005, trees submitted to 10 to $15 \mathrm{kPa}$ soil water tension treatments produced $52 \%$ more fruits ( 68 fruits per tree), than those subjected to a 40 - to $45-\mathrm{kPa}$ soil water tension treatment ( 33 fruits per tree) and to those rainfed (18 fruits per tree) (Figure 3). Tree productivity could have been affected by an outbreak of a foliar disease, preliminarily identified as Colletotrichum sp., which reduced foliar tissue dramatically in 2005 (Esteves, C. 2005, Phytopathologist, Agricultural Experiment Station, University of Puerto Rico, Personal Communication.). Foliar applications of systemic and contact fungicides were used to control the disease.

There are no published data on cultivar Simmonds in Puerto Rico. Four-year average yield reported for eight-year-old avocado trees $\mathrm{cv}$. Fuerte submitted to different water use levels was $57.9 \mathrm{~kg} /$ tree (Michelakis et al., 1993). Another experiment with six-year-old trees using the same cultivar reported cumulative yield of 314 and $379 \mathrm{~kg} /$ tree for wet and dry treatments, respectively, during six years of production 
TABLE 2.-Probability of the $F$ value $(P>F)$ in the analysis of variance by year of canopy volume, fruit weight and fruit number of avocado (cv. Simmonds) as a response to microirrigation treatments scheduled by using tensiometers at Isabela, Puerto Rico.

\begin{tabular}{|c|c|c|c|c|c|c|c|c|c|c|c|c|c|}
\hline \multirow[b]{2}{*}{ Sources of variation } & \multicolumn{5}{|c|}{ Canopy volume } & \multicolumn{4}{|c|}{ Fruit weight } & \multicolumn{4}{|c|}{ Fruit number } \\
\hline & 2003 & 2004 & 2005 & 2006 & 2007 & 2004 & 2005 & 2006 & 2007 & 2004 & 2005 & 2006 & 2007 \\
\hline Block & 0.0034 & 0.0032 & $\mathrm{NS}^{1}$ & 0.0259 & 0.1664 & NS & NS & 0.0013 & 0.0138 & NS & 0.0218 & 0.0027 & 0.0312 \\
\hline Microirrigation treatments & 0.0249 & 0.0113 & 0.0002 & 0.0003 & 0.5407 & NS & 0.0001 & 0.0120 & 0.0119 & NS & 0.0001 & NS & 0.0441 \\
\hline $\mathrm{LSD}^{2}$ & 4.42 & 10.72 & 33.56 & 25.41 & - & - & 13.32 & 19.16 & 22.65 & - & 19.24 & - & 45.86 \\
\hline $\mathrm{CV}^{3}$ & 43.58 & 28.74 & 30.37 & 27.89 & 9.95 & 45.43 & 39.25 & 41.01 & 25.29 & 47.31 & 44.62 & 42.25 & 28.92 \\
\hline
\end{tabular}

${ }^{1} \mathrm{NS}=$ not significant.

${ }^{2} \mathrm{LSD}=$ Fishers protected least significant difference $(\alpha=0.05)$.

${ }^{3} \mathrm{CV}=$ Coefficient of Variation $(\%)$. 


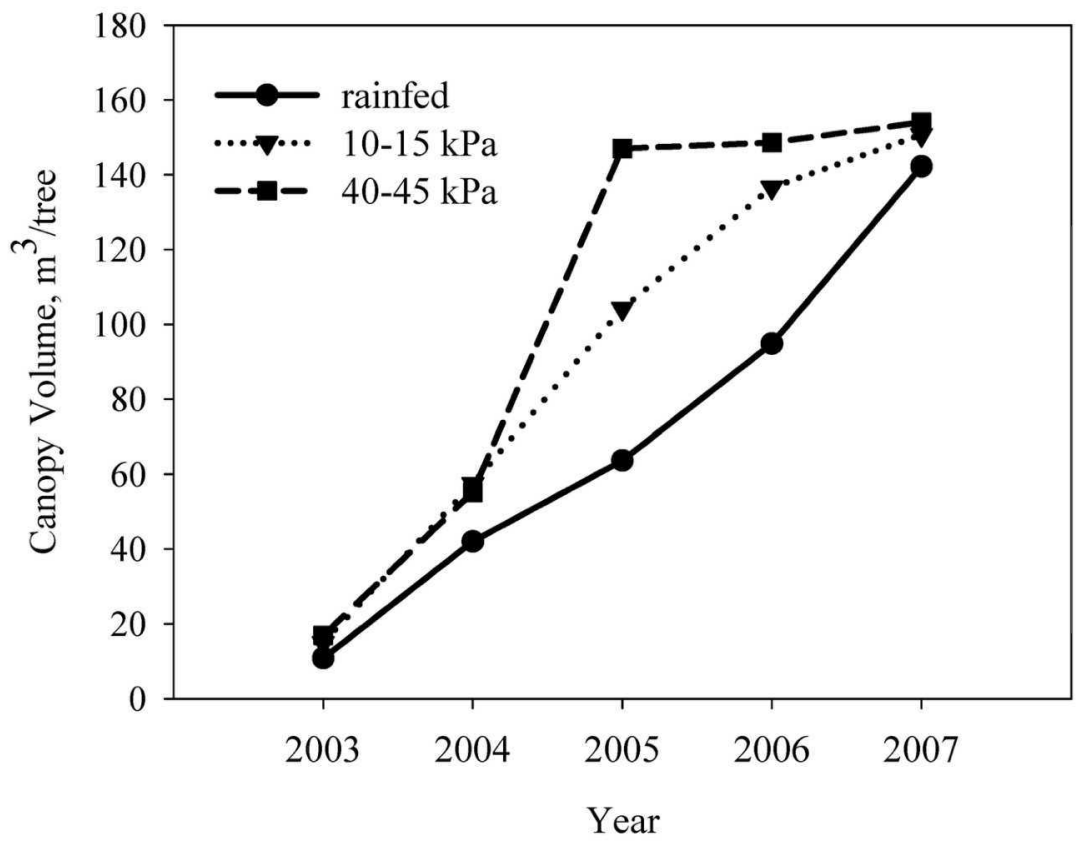

FIGURE 1. Canopy volume response of young avocado trees (ev. 'Simmonds') to microirrigation treatments scheduled by using tensiometers in a Coto clay at Isabela, Puerto Rico.

(Adato and Levinson, 1988). Lahav and Kalmar (1977) reported that yield from a treatment combination of four irrigation intervals and four annual water applications during a six-year period produced a range varying from 41.8 to $37.6 \mathrm{~kg} /$ tree and 62.8 to $52.7 \mathrm{~kg} /$ tree for cultivars Fuerte and Hass, respectively. In California, eight-year-old Hass trees submitted to three irrigation levels, three $\mathrm{N}$ rates, and two $\mathrm{Zn}$ rates produced maximum and minimum yields of 26.06 and $14.92 \mathrm{~kg} /$ tree, respectively (Tekele et al., 1996). Levinson and Adato (1991) suggested that the effect of irrigation on the number of fruits reaching harvest became greater as the experiment progressed. More than half of the trees in the dry treatment yielded $50 \%$ more fruits than average in the sprinkling treatment. Hoffman and du Plessis (1999) reported no significant differences of fruit size and yield for Hass and Fuerte in trees submitted to wet $(30 \mathrm{kPa})$ and dry treatments $(60 \mathrm{kPa})$.

Table 3 includes data on rainfall, number of irrigation events, and amount of irrigation reported in three-month periods; however, ET was estimated daily, and irrigation events and amount of irrigation on a 
TABLE 3.- Estimated evapotranspiration, rainfall, number of irrigation events, irrigation applied to avocado trees cv. Simmonds per microirrigation treatments scheduled by using tensiometers at Isabela, Puerto Rico, during 2003-2005.

\begin{tabular}{|c|c|c|c|c|c|c|c|c|}
\hline \multirow[b]{3}{*}{ Time Period } & \multirow[b]{3}{*}{$\begin{array}{l}\mathrm{ETc}^{1} \\
\mathrm{~mm}\end{array}$} & \multirow[b]{3}{*}{$\begin{array}{c}\text { Rainfall } \\
\mathrm{mm}\end{array}$} & \multicolumn{6}{|c|}{ Microirrigation treatments } \\
\hline & & & \multicolumn{3}{|c|}{10 to $15 \mathrm{kPa}$} & \multicolumn{3}{|c|}{40 to $45 \mathrm{kPa}$} \\
\hline & & & $\begin{array}{c}\text { Irrigation } \\
\text { events }\end{array}$ & $\begin{array}{l}\text { Irrigation } \\
\text { applied }{ }^{2} \\
\text { L/tree }\end{array}$ & $\begin{array}{c}\text { Average weekly } \\
\text { irrigation } \\
\text { L/tree }\end{array}$ & $\begin{array}{c}\text { Irrigation } \\
\text { events }\end{array}$ & $\begin{array}{c}\text { Irrigation } \\
\text { applied } \\
\text { L/tree }\end{array}$ & $\begin{array}{c}\text { Average weekly } \\
\text { irrigation } \\
\mathrm{L} / \text { tree }\end{array}$ \\
\hline \multicolumn{9}{|l|}{2003} \\
\hline January to March & 233 & 177 & 9 & 1,026 & 85.5 & 3 & 342 & 28.5 \\
\hline April to June & 306 & 654 & 11 & 1,254 & 104.5 & 5 & 570 & 47.5 \\
\hline July to September & 315 & 428 & 19 & 2,166 & 180.5 & 6 & 684 & 57.0 \\
\hline October to December & 243 & 759 & 4 & 456 & 38.0 & 3 & 342 & 28.5 \\
\hline Total & 1,097 & 2,018 & 43 & 4,902 & & 17 & 1,938 & \\
\hline \multicolumn{9}{|l|}{2004} \\
\hline January to March & 239 & 309 & 26 & 2,964 & 247.0 & 11 & 1254 & 104.5 \\
\hline April to June & 306 & 398 & 17 & 3,548 & 295.6 & 8 & 2066 & 172.0 \\
\hline July to September & 318 & 394 & 16 & 1,230 & 102.5 & 9 & 816 & 68.0 \\
\hline October to December & 244 & 460 & 13 & 991 & 82.5 & 6 & 698 & 58.0 \\
\hline Total & 1,107 & 1,561 & 72 & 8,733 & & 34 & 4,834 & \\
\hline
\end{tabular}

${ }^{1}$ Crop evapotranspiration estimated using computer program PR-ET V1.02 (http://academic.uprm.edu/abe/PRAGWATER/). Crop coefficient values used were $\mathrm{Ke}_{\text {mid }}=0.85, \mathrm{Ke}_{\text {end }}=0.75$ and maximum tree height $=3.0 \mathrm{~m}$. Length of initial, development, mid and end stages were 50 , 120 , 105 , and 90 days, respectively.

${ }^{2}$ Irrigation applied per treatment measured with water meters.

${ }^{3}$ Values correspond only to March 2005. 
TABLE 3.-(Continued) Estimated evapotranspiration, rainfall, number of irrigation events, irrigation applied to avocado trees cv. Simmonds per microirrigation treatments scheduled by using tensiometers at Isabela, Puerto Rico, during 2003-2005.

\begin{tabular}{|c|c|c|c|c|c|c|c|c|}
\hline \multirow[b]{3}{*}{ Time Period } & \multirow[b]{3}{*}{$\begin{array}{l}\mathrm{ETe}^{1} \\
\mathrm{~mm}\end{array}$} & \multirow[b]{3}{*}{$\begin{array}{c}\text { Rainfall } \\
\text { mm }\end{array}$} & \multicolumn{6}{|c|}{ Microirrigation treatments } \\
\hline & & & \multicolumn{3}{|c|}{10 to $15 \mathrm{kPa}$} & \multicolumn{3}{|c|}{40 to $45 \mathrm{kPa}$} \\
\hline & & & $\begin{array}{l}\text { Irrigation } \\
\text { events }\end{array}$ & $\begin{array}{l}\text { Irrigation } \\
\text { applied }{ }^{2} \\
\mathrm{~L} / \text { tree }^{-}\end{array}$ & $\begin{array}{c}\text { Average weekly } \\
\text { irrigation } \\
\text { L/tree }\end{array}$ & $\begin{array}{c}\text { Irrigation } \\
\text { events }\end{array}$ & $\begin{array}{c}\text { Irrigation } \\
\text { applied } \\
\text { L/tree }\end{array}$ & $\begin{array}{c}\text { Average weekly } \\
\text { irrigation } \\
\mathrm{L} / \text { tree }\end{array}$ \\
\hline \multicolumn{9}{|l|}{2005} \\
\hline January to March & 242 & 363 & $10^{3}$ & 1,086 & 90.5 & $3^{3}$ & 1,166 & 97.0 \\
\hline April to June & 307 & 728 & 8 & 833 & 69.4 & 0 & 149 & 12.0 \\
\hline July to September & 316 & 563 & 15 & 1,206 & 100.5 & 1 & 168 & 14.0 \\
\hline October to December & 239 & 560 & 10 & 702 & 58.5 & 2 & 401 & 33.4 \\
\hline Total & 1,104 & 2,214 & 33 & 3,829 & & 6 & 1,884 & \\
\hline
\end{tabular}

${ }^{1}$ Crop evapotranspiration estimated using computer program PR-ET V1.02 (http://academic.uprm.edu/abe/PRAGWATER/). Crop coefficient values used were $\mathrm{Kc}_{\text {mid }}=0.85, \mathrm{Kc}_{\text {end }}=0.75$ and maximum tree height $=3.0 \mathrm{~m}$. Length of initial, development, mid and end stages were 50,120 , 105 , and 90 days, respectively.

${ }^{2}$ Irrigation applied per treatment measured with water meters.

${ }^{3}$ Values correspond only to March 2005. 


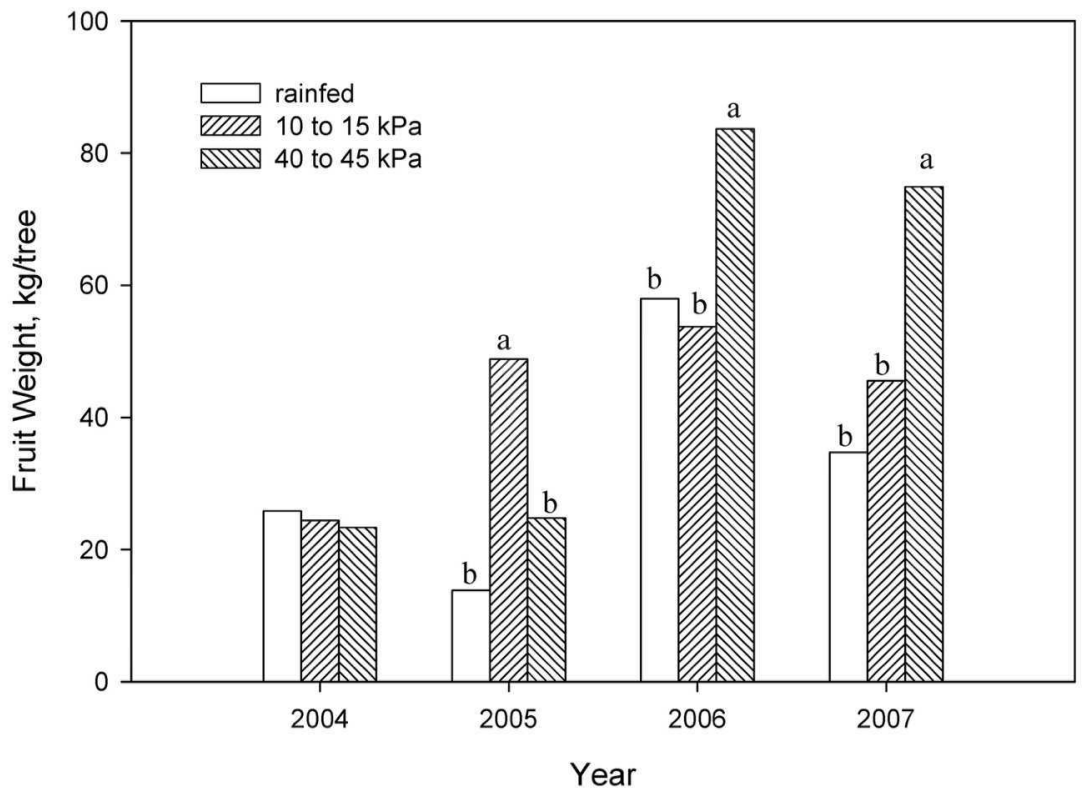

FIGURE 2. Average fruit weight produced by young avocado trees (cv. Simmonds) affected by microirrigation treatments scheduled by using tensiometers in a Coto clay at Isabela, Puerto Rico. (Means of fruit weight within microirrigation treatments for each year with the same letter are not significantly different at the $5 \%$ level.)

weekly basis (amount of irrigation applied for 2006 and 2007 is not shown). During 2003, avocado trees submitted to the 10 - to $15-\mathrm{kPa}$ treatment required 43 irrigation events, totaling 4,902 L/tree combined with $2,018 \mathrm{~mm}$ of rainfall to maintain soil moisture near field capacity (Table 3). To maintain a soil water tension less than 40 to $45 \mathrm{kPa}$, only seventeen irrigation events were necessary $(1,938 \mathrm{~L} /$ tree $)$. Trees needed frequent irrigation from July to September 2003, regardless of microirrigation treatment (Table 3 ). This period was associated with higher temperatures and wind gusts. In 2004, trees required 72 and 34 microirrigation events, respectively, to satisfy the 10 - to 15 - and 40 - to $45-\mathrm{kPa}$ treatment threshold. Rainfall recorded during that year $(1,561 \mathrm{~mm})$ was less than in previous years. Each year from 2003 to 2005, avocado trees doubled their canopy volume, thus increasing evapotranspiration and therefore requiring more frequent irrigation. Only six irrigation events during 2005 were needed to maintain soil tension at less than 40 to $45 \mathrm{kPa}$. The number of irrigation events for the 40 - to $45-\mathrm{kPa}$ treatment was 39, 47 and $18 \%$ less than the irrigation events required to maintain soil at field capacity in 2003, 2004, and 2005, respectively 


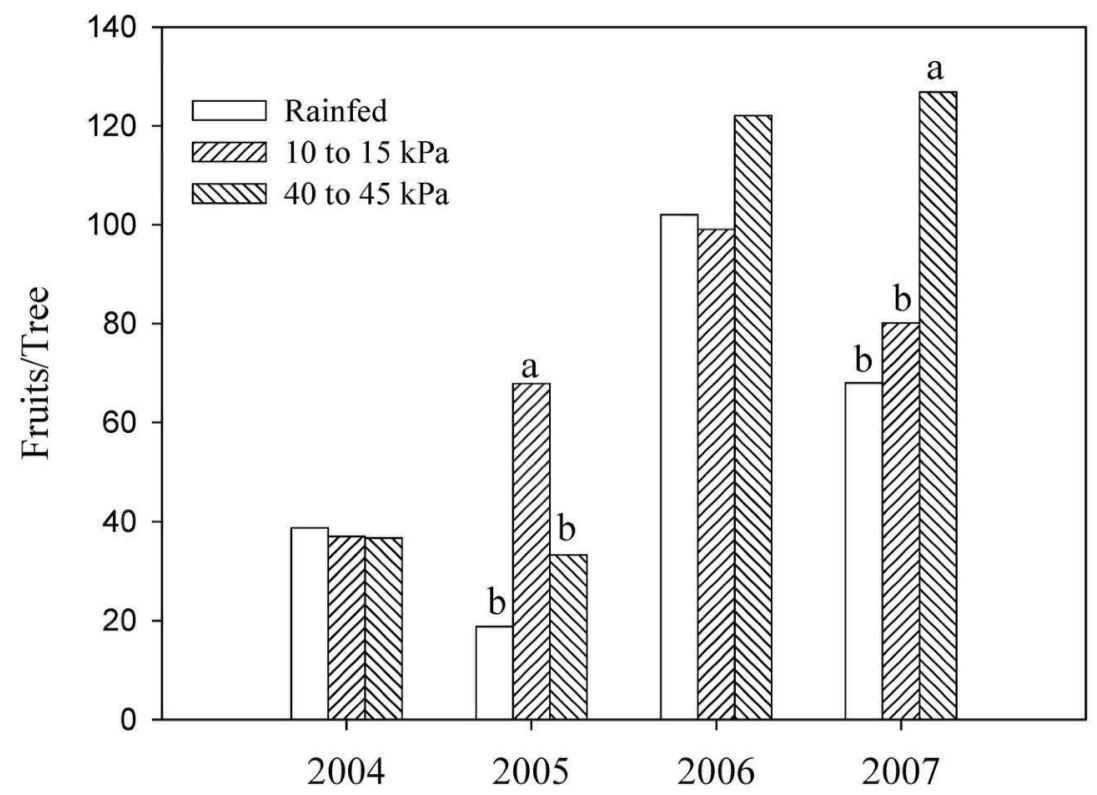

Year

FIGURE 3. Average fruit number produced by young avocado trees (ev. Simmonds) affected by microirrigation treatments scheduled by using tensiometers in a Coto clay at Isabela, Puerto Rico. (Means of fruit number within microirrigation treatments for each year with the same letter are not significantly different at the $5 \%$ level.)

(Table 3). In terms of the amount of microirrigation applied, the 40 to $45-\mathrm{kPa}$ treatment required 39,55 , and $49 \%$ less irrigation than the 10 to $15 \mathrm{kPa}$ in the same corresponding years. Rainfall registered at Isabela surpassed ET estimates for most of the growing season (Table 3). The period from April to September represented about 57\% annual ET from 2003 to 2005 . According to ET estimates, the sole period in which trees required irrigation was January to March 2003 (Table 3). However, tensiometer readings indicated that the orchard required irrigation to avoid water stress caused by low soil available water. This fact of greater rainfall than estimated water demand by the trees does not take into account that trees may be in stress by temporary water shortage in the soil profile. Another possibility may be that the computer model underestimated ET under prevailing conditions at Isabela.

The data obtained in this research indicate that $\mathrm{cv}$. Simmonds adapted well to the conditions observed in northern Puerto Rico. Dur- 
ing the six-year period, no symptoms of Phytophthora cinnamomi were observed in the orchard, possibly because of the high water percolation typically shown by soil pertaining to Coto clay series. High water percolation reduces the chances of fungal infection and eventual tree death. The avocado root system does not tolerate high soil moisture content in the profile. In addition, maintaining the soil at high depletion level reduces the chance of Phytophthora cinnamomi infestation. Although in northern Puerto Rico high and well-distributed rainfall is observed throughout the year, it is insufficient to maintain adequate tree growth rate and increased yield. In that environment, microirrigation is necessary for a farmer to maximize yield. Maintaining soil tension up to 40 to $45 \mathrm{kPa}$ significantly increases yield and growth, with water savings up to $47 \%$ in a three-year period in comparison with maintaining soil at field capacity. Data obtained in this research also suggest that avocado is sensitive enough to reduce yield when distinguishing as low as $5 \%$ of available water in the soil profile.

We recommend the use of tensiometers to schedule irrigation for avocado in the Isabela region because it is relatively simple and relatively inexpensive, compared with the high cost associated with pumping non-required water. However, the use of tensiometers requires some degree of maintenance. Information on the response of trees to soil water tension is transferable among locations, but the irrigation amount needed to reach a specific soil water tension is not. Irrigation is sitespecific and depends on several factors, such as soil physical properties and climatic variables.

\section{LITERATURE CITED}

Adato, I. and B. Levinson, 1988. Influence of daily intermittent drip irrigation on avocado (cv. Fuerte) fruit yield and trunk growth. J. Hort. Sci. 63(4):675-685.

Agricultural Experiment Station (AES), 1998. Conjunto Tecnológico para la Producción de Aguacates. College of Agricultural Sciences, University of Puerto Rico-Mayagüez. Publication 112 (Revised Edition).

Allen, R. G., L. S. Pereira, D. Raes and M. Smith, 1998. Crop evapotranspiration guidelines for computing crop water requirements. FAO. Irrigation and Drainage Paper 56, Food and Agriculture Organization of the United Nations, Rome.

Beinroth, F. H., R. J. Engel, J. L. Lugo, C. Santiago, S. Ríos and G. R. Brannon, 2003. Updated taxonomic classification of the soils of Puerto Rico, 2002. Bulletin 303. Agricultural Experiment Station, College of Agricultural Sciences, University of Puerto Rico, Mayagüez Campus.

Crane, J. H., C. F. Balerdi and C. W. Campbell, 2000. The avocado. Cooperative Extension Service. Institute of Food and Agricultural Sciences. University of Florida.

Crane, J. H., C. F. Balerdi and I. Maguire, 2005. Avocado growing in the Florida home landscape. Florida Cooperative Extension Service, Institute of Food and Agricultural Sciences, University of Florida. http://edis.ifas.ufl.edu/MG213.

Goenaga, R. and H. Irizarry, 1995. Yield performance of banana irrigated with fraction of Class A evaporation in a semiarid environment. Agron. J. 87:172-176. 
Goyal, M. R., 1989. Irrigation research and extension progress in Puerto Rico. Agricultural Experiment Station. University of Puerto Rico.

Hoffman, J. E. and S. F. du Plessis, 1999. Seasonal water requirements of avocado trees grown under subtropical conditions. Revista Chapingo, Serie Horticultura 5:191194.

Harmsen, E. W. and A. González, 2005. A computer program for estimating crop evapotranspiration in Puerto Rico. J. Agric. Univ. P.R. 89(1-2):107-113.

Li, Y. C., 2000. Using tensiometers for irrigation scheduling in tropical fruit groves. Fact sheet TR002. Florida Cooperative Extension Service, IFAS. University of Florida.

Lahav, E. and D. Kalmar, 1977. Water requirements of avocado in Israel. II. Influence on yield, fruit growth and oil content. Aust. J. Agric. Res. 28:869-877.

Levinson, B. and I. Adato, 1991. Influence of reduced rates of water and fertilizer application using daily intermittent drip irrigation on the water requirements, root development and responses of avocado trees (cv. 'Fuerte'). J. Hort. Sci. 66:449-463.

Michelakis, N., E. Vougioukalou and G. Clapaki, 1993. Water use, wetted soil volume, root distribution and yield of avocado under drip irrigation. Agric. Water Manage. 24:119-131.

Román, F., C. Flores and G. Ruiz-Sifre, 1997. Evaluación de doce genotipos de china (Citrus sinensis) en dos patrones. J. Agric. Univ. P. R. 81(1-2):79-82.

Takele, E., J. L. Meyer, M. L. Arpaia, D. E. Stottlemeyer and G. W. Witney, 1996. Economic analysis of irrigation and fertilization management of avocados. HortScience 31(1):156-159.

SAS Institute, 2002. SAS/STAT Guide, V8.02; SAS Institute, Inc. Cary, NC.

World Horticultural Trade \& US Export Opportunities (CWHTUSO), 2006. Avocado situation and outlook for selected countries. Global Production and Trade. 